\title{
A STUDY ON RURAL AND URBAN CONSUMER BUYING BEHAVIOUR TOWARDS FOOD PRODUCTS OF FARMER PRODUCER ORGANIZATIONS
}

\author{
S. VANATHI ${ }^{{ }^{*}} \&$ S. D. SIVAKUMAR ${ }^{2}$ \\ ${ }^{l}$ PG Scholar, Department of Agricultural and Rural Management, Tamil Nadu Agricultural University, \\ Coimbatore, Tamil Nadu, India \\ ${ }^{2}$ Professor \& Director, Directorate of Agribusiness Development, Tamil Nadu Agricultural University, \\ Coimbatore, Tamil Nadu, India
}

\begin{abstract}
Farmer Producer Organizations (FPOs) started the retail store for food products in rural, semi urban and urban areas targeting the consumers preferring healthy and quality food products. With the above background, the main aim of the study is to analyse the buying behaviour of rural and urban consumers towards FPOs food products. A sample size of 80 respondents was taken for the study. The buying behaviour of rural and urban consumers was influenced by the monthly income of the households. Urban consumers spent more money for the purchase of food products in FPO retail stores when compared with rural consumers. The main reason for buying the FPOs products by both rural and urban consumers were quality and chemical free of the products.

KEYWORDS: Farmer Producer Organizations, Rural Consumer \& Urban Consumer
\end{abstract}

Received: May 03, 2019; Accepted: May 24, 2019; Published: Jun 13, 2019; Paper Id.: IJASRAUG20199

\section{INTRODUCTION}

India is predominantly a rural country and 68.8 per cent of the country's population and 72.4 per cent of workforce resided in rural areas (Census, 2011). Rural as villages with fewer than 5,000 residents, a population density less than 400 people per square kilometre and at least 75 percent of the male working population employed as agriculturists (NSSO, 2018). Rural economy constitutes 46 per cent of national income. Urban area is a place having a minimum population of 5,000 of density 400 persons per square kilometre or higher and $75 \%$ plus of the male working population employed in non-agricultural activities. Places administered by a municipal corporation, cantonment board or notified town area committee are automatically considered urban areas (Census, 2011).

Packaging, price and quality were the major factors influencing the rural consumers for buying the food products. Advertising is an important tool for creating a basic awareness of the product to rural consumers (Morden, 1991). Rural consumers expect quality products at a reasonable price (Madhavi and Kumar, 2006). The buying behaviour of the rural consumers was mainly influenced by socio-economic conditions, cultural environment, literacy level, occupation, geographical location, efforts on the part of sellers, and exposure to the media. Social norms, tradition, cast, social customs have greater influence on consumer behaviour in rural areas than urban areas(Mithileshwar, 2007). Rural consumers gave more importance to the quality of the products rather than the normative influences or social appeal vides celebrity endorsements in the mass media(Anilkumar, 2014). Rural Consumers purchase goods based on availability, price, discount offers and gifts (Williams, 2018). 
The urban consumer's preferred mostly branded products compared to rural consumers. The most significant factors influencing buying decisions of urban consumers were accessibility, quality, regular supply, door delivery and the mode of payment (Kubendran and Vanniarajan, 2005). In rural areas, pricing is given more consideration than brand name, while in urban areas, brand name overtakes pricing factor(Singh et al., 2014). Thus from study summarized that rural consumers buying behaviour were influenced by reasonable price, quality, culture, tradition, media and socio economic conditions and urban consumers buying behaviour were influenced by quality, brand, door delivery and mode of payment.

The objective of this study was to identify the buying behaviour of rural and urban consumers towards FPOs food products. The total number of FPOs registered in India was 5000 (NABARD- Potential Linked Credit Plan 2019-20) and Tamil Nadu was 232 (SFAC and NABARD, 2019). Most of the FPOs were engaged in production of traditional food products, among them only few FPOs have own retail outlets in rural, semi urban and urban areas.

\section{METHODOLOGY}

\section{Sampling Design and Data Collection}

Coimbatore, Erode and Namakkal districts in Tamil Nadu were purposively selected for the study. In this study two FPOs in rural area(Erode and Namakkal)and two FPOs in urban area (Coimbatore) were selected for the study. In each of the selected FPO retail outlets, 20 customers were selected randomly. Thus 40 respondents from each area and on the whole 80 sample respondents were selected for the study.

Primary data required for the study were collected through personal interview with the help of an interview schedule. Percentage analysis and Garrett ranking technique used for analyse the data.

\section{RESULTS AND DISCUSSIONS}

\section{Socio - Demographic Characteristics}

Classifications of sample respondents based on gender are presented in table 1. It could be inferred that most of the respondents of rural (87.50 per cent) and urban (52.50 per cent) were male. Thus the study clearly indicated that male customers were visiting FPO retail stores when compared with females. The table 2 represented that most of the urban ( 97.50 per cent) and rural (92.50 per cent)consumers were married people. It could be observed from the table 3 that the majority of the customers of rural (32.50 per cent) and urban FPO retail store (62.50 per cent) were middle aged (31 - 40 years) people.

Educational profile of the rural (27.50 per cent) and urban (67.50 per cent) sample indicates that most of the respondents were graduates which are presented in table 4. It could be seem from the table 5 that most of the rural respondents were farmers (42.50 per cent) and urban respondents were business peoples (57.50 per cent). The table 6 indicated that the majority of the rural (47.50 per cent) and urban (77.50 percent) respondents were having small family size $(\leq 4$ members $)$.

It could be summarized from the demographic characteristics of the sample respondents that the majority of the rural and urban consumers were middle aged graduated married male from the small size family. The occupation of majority of the rural consumers were agriculture where as urban consumers were business class peoples. Hence educational qualification, occupation and Income of respondents have decided the buying behaviour of branded food items (Vyas et al., 2016). 


\section{CONSUMER BUYING BEHAVIOUR}

Consumers most preferred food products of FPO retail store are presented in table 7. In rural FPOs retail store 80 per cent of the respondents purchased Jaggery and sugar, snacks and millets. In urban FPOs retail store 67.50 per cent of the respondents purchased oil followed by 62.50 per cent of the respondents were buying jaggery and sugar. Both rural and urban respondents purchased jaggery and sugar in more when compared to other products. In rural FPO retail store sales of pulses, ready mix, spices and honey were less because of the premium price and rural respondents consumes their own produce of pulses and spices. Rural consumers did not prefer ready mix products. They were more willing to use organic products. This could relate back to the fact that rural consumers grow and consume more of their own produce (Cullen and Kingston, 2009). In urban FPO retail store the sales of rava and avul were very low because most of the respondents not preferred these products.

Travelling distance from consumers home to FPO retail store is presented in table 8. Most of the rural consumers come from $\leq 1 \mathrm{~km}$ (70per cent). The majority of the urban consumers come from 5.1 to $10 \mathrm{~km}$ (47.50 per cent). Hence this study revealed that majority of the rural consumers of FPO retail store was local people.

It could be observed from the table 9 that 85 per cent of the rural consumers purchase the products at anytime. But majority of the urban consumers (65 per cent) purchase the products in weekends since most of the urban consumers were business peoples.

It could be inferred from the table 10 that majority of the rural (80per cent) and urban ( 90 per cent) consumers were regular buyers of the FPOs food products. Urban consumers were purchasing regularly in a high percentage when compared with rural consumers.

The respondents' family monthly income was divided into six categories and it was represented in table 11 . Majority of the rural and urban consumers belonged to high income group (above $₹$ 55000). The table shows that the high income people were purchasing the FPOs food products more when compared with other income groups.

It could be observed from the table 12 that the most of the rural consumers spent $\square 501-1000$ (25 per cent) for purchasing the food products. The majority of the urban consumers spent $\square 2001-3000$ in FPO retail store. This implies that rural consumers spent only lesser amount for purchasing in FPO retail store when compared with urban consumers.

\section{Factors Influencing the Purchase of Food Products of FPO}

Major factors of the FPO food products influencing the purchase of food products are displayed in figure 1. Majority of the rural customers (79.07 per cent) ranked first for quality followed by high nutrient content (69.42 per cent). No adulteration ( 65.9 per cent) was ranked third followed by no preservatives ( 64.77 per cent) while price (19.25 per cent) was ranked last. The rural people try not to purchase or consume products with artificial additives and preservatives (Cullen and Kingston, 2009).

Most of the urban customers ranked first for quality followed by no adulteration and preservatives while price was ranked last. Hence quality was the major factors influencing the rural and urban consumers for buying the FPOs food products (Naspetti et al., 2008). 


\section{CONCLUSIONS}

This study concluded that buying behaviour of rural and urban consumers were highly influenced by the monthly income of the households. The majority of the rural and urban consumers were high income people. Urban consumers spent more money on purchasing the FPO food products when compared with rural consumers. The main reason for rural and urban consumers buying the FPOs food products were high quality, nutrient content, no adulteration and free from preservatives. This implies that both rural and urban consumers were buying the products based on quality and not price.

\section{REFERENCES}

1. Anilkumar, N. S., \& Joseph, J. (2014). A Contrasting Evaluation of Consumer Purchase Attitude-Behavior of Urban-Rural Working Women Consumers Towards White-Brown Durables, a Study With Specific Relevance to Kochi, Kerala. Journal of Global Economics, 3(2).

2. Census of India, (2011). Retrieved from http://censusindia.gov.in/pca/Searchdata.aspx

3. Cullen, F., \& Kingston, H. (2009). Analysis of rural and urban consumer behavior toward new food products using a foodrelated lifestyle instrument. Journal of Foodservice Business Research, 12(1), 18-41.

4. Farmer Producers' Organizations (FPOs): Status, Issues \& Suggested Policy Reforms. (2019-20). Retrieved from https://www.nabard.org/

5. Kubendran, V., \&Vanniarajan, T. (2005). Comparative analysis of rural and urban consumers on milk consumption. Indian journal of marketing, 35(12).

6. Kumar, S. A., \&Madhavi, C. (2006). Rural Marketing For-FMCG. Indian Journal of Marketing, 36(4).

7. Manjunath, S., \& Reginald, S. (2016). Customer satisfaction in fast food industry: a case study of Mysore. International Journal of Research in Finance and Marketing, 6(5), 72-78.

8. Mithileshwar, J. (2007). Rural marketing in India. Kotler Philip, Keller Kevin Lane, Koshy Abraham \&JhaMithileshwar, Marketing Management, Al-A6.

9. Morden A.R. 1991. Elements of Marketing. London: D.P. Publication Ltd.

10. NABARD portal on Farmer Producer Organizations, (2019). Retrieved from https://nabfpo.in/images/staticFPO. html.

11. Naspetti, S., \&Bodini, A. (2008). Consumer perception of local and organic products: substitution or complementary goods?. The International Journal of Interdisciplinary Social Sciences, 3(2), 111-122.

12. National Sample Survey Office, (2018). Retrieved from http://www.mospi.gov.in/national-sample-survey-office-nsso.

13. Singh, S., Kumar, S., Goel, T., \& Chawla, S. (2014). Impact of brand on rural and urban consumer behavior- A study on mobile phone buyers. Journal of Business and Management, 16(5), 73-78.

14. Small Farmers Agri-business Consortium.(2019).Retrieved from http://sfacindia.com/List-of-FPO-Statewise.aspx

15. Vyas, R., Sharma, J. K., Sharma, R. B. (2016). A study on consumer behavior towards select branded food items. Journal of Business and Management,18 (8), 01 -08. 
Table 1: Classification of the Respondents Based on Gender

$\mathbf{n}=\mathbf{8 0}$

\begin{tabular}{|c|c|c|c|c|}
\hline \multirow{2}{*}{ Gender } & \multicolumn{2}{|c|}{ Rural } & \multicolumn{2}{c|}{ Urban } \\
\cline { 2 - 5 } & Respondents & Percentage & Respondents & Percentage \\
\hline Male & 35 & 87.50 & 21 & 52.50 \\
\hline Gender & 5 & 12.50 & 19 & 47.50 \\
\hline Total & $\mathbf{4 0}$ & $\mathbf{1 0 0 . 0 0}$ & $\mathbf{4 0}$ & $\mathbf{1 0 0 . 0 0}$ \\
\hline
\end{tabular}

Table 2: Classification of the Respondents Based on Marital Status

$$
\mathbf{n}=\mathbf{8 0}
$$

\begin{tabular}{|l|c|c|c|c|}
\hline \multirow{2}{*}{ Marital Status } & \multicolumn{2}{|c|}{ Rural } & \multicolumn{2}{c|}{ Urban } \\
\cline { 2 - 5 } & Respondents & Percentage & Respondents & Percentage \\
\hline Married & 37 & 92.50 & 39 & 97.50 \\
\hline Unmarried & 3 & 7.50 & 1 & 2.50 \\
\hline Total & $\mathbf{4 0}$ & $\mathbf{1 0 0 . 0 0}$ & $\mathbf{4 0}$ & $\mathbf{1 0 0 . 0 0}$ \\
\hline
\end{tabular}

Table 3: Classification of Sample Respondents Based on Age

$$
\mathbf{n}=\mathbf{8 0}
$$

\begin{tabular}{|c|c|c|c|c|}
\hline \multirow{2}{*}{ Age (Years) } & \multicolumn{2}{|c|}{ Rural } & \multicolumn{2}{c|}{ Urban } \\
\cline { 2 - 5 } & Respondents & Percentage & Respondents & Percentage \\
\hline $20-30$ & 6 & 15.00 & 3 & 7.50 \\
\hline $31-40$ & 13 & 32.50 & 25 & 62.50 \\
\hline $41-50$ & 12 & 30.00 & 8 & 20.00 \\
\hline $51-60$ & 7 & 17.50 & 3 & 7.50 \\
\hline Above 60 & 2 & 5.00 & 1 & 2.50 \\
\hline Total & $\mathbf{4 0}$ & $\mathbf{1 0 0 . 0 0}$ & $\mathbf{4 0}$ & $\mathbf{1 0 0 . 0 0}$ \\
\hline
\end{tabular}

Table 4: Classification of Sample Respondents Based on Educational Level

$$
\mathbf{n}=\mathbf{8 0}
$$

\begin{tabular}{|l|c|c|c|c|}
\hline \multirow{2}{*}{$\begin{array}{c}\text { Educational } \\
\text { Qualification }\end{array}$} & \multicolumn{2}{|c|}{ Rural } & \multicolumn{2}{c|}{ Urban } \\
\cline { 2 - 5 } & Respondents & Percentage & Respondents & Percentage \\
\hline Illiterate & 5 & 12.50 & 2 & 5.00 \\
\hline SSLC & 9 & 22.50 & 3 & 7.50 \\
\hline HSC & 5 & 12.50 & 1 & 2.50 \\
\hline Diploma & 8 & 20.00 & 4 & 10.00 \\
\hline Graduate & 11 & 27.50 & 27 & 67.50 \\
\hline Post graduate & 2 & 5.00 & 3 & 7.50 \\
\hline \multicolumn{1}{|c|}{ Total } & $\mathbf{4 0}$ & $\mathbf{1 0 0 . 0 0}$ & $\mathbf{4 0}$ & $\mathbf{1 0 0 . 0 0}$ \\
\hline
\end{tabular}

Table 5: Classification of Sample Respondents Based on Family Size

$$
\mathbf{n}=\mathbf{8 0}
$$

\begin{tabular}{|c|c|c|c|c|}
\hline \multirow{2}{*}{ Family Size } & \multicolumn{2}{|c|}{ Rural } & \multicolumn{2}{c|}{ Urban } \\
\cline { 2 - 5 } & Respondents & Percentage & Respondents & Percentage \\
\hline$\leq 4$ & 19 & 47.50 & 31 & 77.50 \\
\hline $5-7$ & 18 & 45.00 & 9 & 22.50 \\
\hline $8-10$ & 3 & 7.50 & & \\
\hline Total & $\mathbf{4 0}$ & $\mathbf{1 0 0 . 0 0}$ & $\mathbf{4 0}$ & $\mathbf{1 0 0 . 0 0}$ \\
\hline
\end{tabular}


Table 6: Classification of Sample Respondents Based on Occupation

$$
\mathbf{n}=\mathbf{8 0}
$$

\begin{tabular}{|l|c|c|c|c|}
\hline \multirow{2}{*}{ Occupation } & \multicolumn{2}{|c|}{ Rural } & \multicolumn{2}{c|}{ Urban } \\
\cline { 2 - 5 } & Respondents & Percentage & Respondents & Percentage \\
\hline Farmer & 17 & 42.50 & - & - \\
\hline Business & 10 & 25.00 & 23 & 57.50 \\
\hline Employees & 13 & 32.50 & 17 & 42.50 \\
\hline \multicolumn{1}{|c|}{ Total } & $\mathbf{4 0}$ & $\mathbf{1 0 0 . 0 0}$ & $\mathbf{4 0}$ & $\mathbf{1 0 0 . 0 0}$ \\
\hline
\end{tabular}

Table 7: Rural and Urban Consumers Most Preferred Food Products in FPOs Retail Store

$\mathbf{n}=\mathbf{8 0}$

\begin{tabular}{|c|c|c|c|c|c|c|}
\hline \multirow{3}{*}{ Products } & \multicolumn{4}{|c|}{ Number of Respondents } & \multirow{3}{*}{$\begin{array}{l}\text { Total No. of } \\
\text { Respondents }\end{array}$} & \multirow{3}{*}{ Percentage } \\
\hline & \multicolumn{2}{|c|}{ Rural $(n=40)$} & \multicolumn{2}{|c|}{ Urban $(n=40)$} & & \\
\hline & $\begin{array}{c}\text { No. of } \\
\text { Respondents }\end{array}$ & Percentage & $\begin{array}{c}\text { No. of } \\
\text { Respondents }\end{array}$ & Percentage & & \\
\hline Jaggery and sugar & 32 & 80.00 & 25 & 62.50 & 57 & 71.25 \\
\hline Snacks & 32 & 80.00 & 20 & 50.00 & 52 & 65.00 \\
\hline Millet rice & 32 & 80.00 & 14 & 35.00 & 46 & 57.5 \\
\hline Oil & 7 & 17.50 & 27 & 67.50 & 34 & 42.5 \\
\hline Millet flour & 11 & 27.50 & 17 & 42.50 & 28 & 35.00 \\
\hline Rice & 9 & 22.50 & 12 & 30.00 & 21 & 26.25 \\
\hline Pickles & 8 & 20.00 & 12 & 30.00 & 20 & 25.00 \\
\hline Pulses & 2 & 5.00 & 17 & 42.50 & 19 & 23.75 \\
\hline Avul & 15 & 37.50 & 4 & 10.00 & 19 & 23.75 \\
\hline Readymix & 1 & 2.50 & 18 & 45.00 & 19 & 23.70 \\
\hline
\end{tabular}

Table 8: Travelling Distance to FPO Retail Store (in km)

$\mathbf{n}=\mathbf{8 0}$

\begin{tabular}{|c|c|c|c|c|}
\hline Travelling Distance to & \multicolumn{2}{|c|}{ Rural } & \multicolumn{2}{c|}{ Urban } \\
\cline { 2 - 5 } FPO Retail Store (km) & Respondents & Percentage & Respondents & Percentage \\
\hline$\leq 1$ & 28 & 70.00 & 3 & 7.50 \\
\hline $1.1-5$ & 12 & 30.00 & 15 & 37.50 \\
\hline $5.1-10$ & - & - & 19 & 47.50 \\
\hline$>10$ & - & - & 3 & 7.50 \\
\hline Total & $\mathbf{4 0}$ & $\mathbf{1 0 0 . 0 0}$ & $\mathbf{4 0}$ & $\mathbf{1 0 0 . 0 0}$ \\
\hline
\end{tabular}

Table 9: Preferred Days for Purchase of Rural and Urban Consumers

$\mathrm{n}=\mathbf{8 0}$

\begin{tabular}{|c|c|c|c|c|}
\hline \multirow{2}{*}{$\begin{array}{c}\text { Preferred Days } \\
\text { for Purchase }\end{array}$} & \multicolumn{2}{|c|}{ Rural } & \multicolumn{2}{c|}{ Urban } \\
\cline { 2 - 5 } & Respondents & Percentage & Respondents & Percentage \\
\hline Anytime & 34 & 85.00 & 7 & 17.50 \\
\hline Weekdays & 3 & 7.50 & 7 & 17.50 \\
\hline Weekends & 3 & 7.50 & 26 & 65.00 \\
\hline Total & $\mathbf{4 0}$ & $\mathbf{1 0 0 . 0 0}$ & $\mathbf{4 0}$ & $\mathbf{1 0 0 . 0 0}$ \\
\hline
\end{tabular}

Table 10: Frequency of Buying of Rural and Urban Consumers

$\mathbf{n}=\mathbf{8 0}$

\begin{tabular}{|c|c|c|c|c|}
\hline \multirow{2}{*}{$\begin{array}{c}\text { Frequency of } \\
\text { Buying }\end{array}$} & \multicolumn{2}{|c|}{ Rural } & \multicolumn{2}{c|}{ Urban } \\
\cline { 2 - 5 } & Respondents & Percentage & Respondents & Percentage \\
\hline Regular buyer & 32 & 80.00 & 36 & 90.00 \\
\hline Occasional buyer & 8 & 20.00 & 4 & 10.00 \\
\hline Total & $\mathbf{4 0}$ & $\mathbf{1 0 0 . 0 0}$ & $\mathbf{4 0}$ & $\mathbf{1 0 0 . 0 0}$ \\
\hline
\end{tabular}


Table 11: Family Monthly Income of Rural and Urban Consumers

$\mathbf{n}=\mathbf{8 0}$

\begin{tabular}{|c|c|c|c|c|}
\hline \multirow{2}{*}{$\begin{array}{c}\text { Family Monthly } \\
\text { Income } \\
(₹)\end{array}$} & \multicolumn{2}{|c|}{ Rural } & \multicolumn{2}{c|}{ Urban } \\
\cline { 2 - 5 } & Respondents & Percentage & Respondents & Percentage \\
\hline$\leq 15000$ & 3 & 7.50 & 1 & 2.50 \\
\hline $15001-25000$ & 6 & 15.00 & 2 & 5.00 \\
\hline $25001-35000$ & 5 & 12.50 & 4 & 10.00 \\
\hline $35001-45000$ & 6 & 15.00 & 8 & 20.00 \\
\hline $45001-55000$ & 7 & 17.50 & 9 & 22.50 \\
\hline Above 55000 & 13 & 32.50 & 16 & 40.00 \\
\hline Total & $\mathbf{4 0}$ & $\mathbf{1 0 0 . 0 0}$ & $\mathbf{4 0}$ & $\mathbf{1 0 0 . 0 0}$ \\
\hline
\end{tabular}

Table 12: Monthly Amount Spent in FPO Retail Store of Rural and Urban Consumers

$$
\mathbf{n}=\mathbf{8 0}
$$

\begin{tabular}{|c|c|c|c|c|}
\hline Monthly Money Spent in & \multicolumn{2}{|c|}{ Rural } & \multicolumn{2}{c|}{ Urban } \\
\cline { 2 - 5 } FPO Retail Store $(₹)$ & Respondents & Percentage & Respondents & Percentage \\
\hline$\geq 500$ & 8 & 20.00 & 5 & 12.50 \\
\hline $501-1000$ & 10 & 25.00 & 3 & 7.50 \\
\hline $1001-1500$ & 6 & 15.00 & 7 & 17.50 \\
\hline $1501-2000$ & 4 & 10.00 & 5 & 12.50 \\
\hline $2001-3000$ & 7 & 17.50 & 9 & 22.50 \\
\hline $3001-4000$ & 2 & 5.00 & 4 & 10.00 \\
\hline Above 4000 & 3 & 7.50 & 7 & 17.50 \\
\hline Total & $\mathbf{4 0}$ & $\mathbf{1 0 0 . 0 0}$ & $\mathbf{4 0}$ & $\mathbf{1 0 0 . 0 0}$ \\
\hline
\end{tabular}

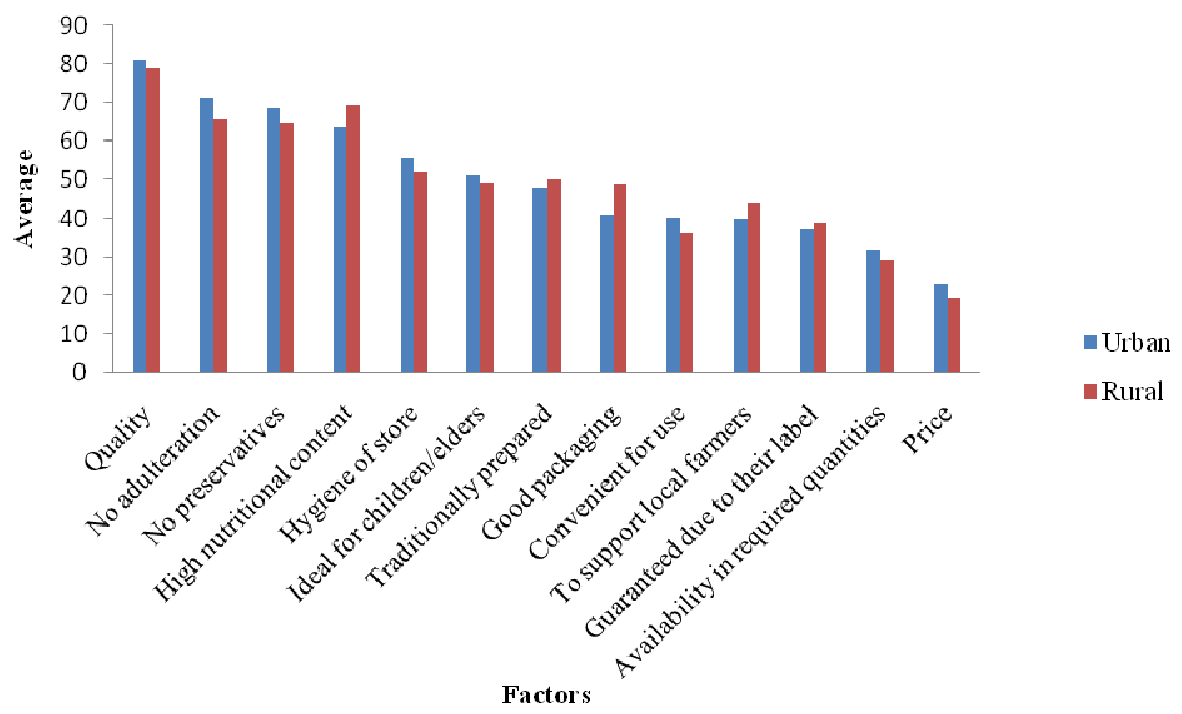

Figure 1: Major Factors Influencing the Purchase of Food Products of FPO 
